\title{
Diana Oboleńska*
}

University of Gdańsk

\section{EMBLEMS AS HIEROGLYPHS OF THE IMAGINATION. THE BLACK SQUARE BY KAZIMIR MALEVICH}

\begin{abstract}
The article assumes a type of comparative-sensual experiment based on the concept of the esoteric emblem, and the form of artistic expression which is 'The Black Square' by Kazimir Malevich. By applying one concept to another, a positive result is obtained, which suggests another way of interpreting this suprematic painting, as an imaginary experience.
\end{abstract}

Keywords: Black Square, Kazimir Malevich, esoteric emblem

In December 1915, Petrograd was relatively warm. An additional warming of the atmosphere of this uneasy, undistinguished capital took place at the end of the year thanks to the final exhibition of futurist paintings called " 0.10 ", where the suprematist work of Kazimir Malevich entitled The Black Square was presented for the first time. The scandal that this exhibition sparked in the world of culture served as excellent advertisement for the newly developing movement in art that came to be known as Suprematism. Today, this canvas finds itself in the museum collection of the Tretyakov Gallery in Moscow and is part of the permanent exhibition there. In 2015, the Gallery released a small well-illustrated catalogue devoted to one of the most intriguing works of Russian art of the twentieth century - The Black Square. My mention of this is no coincidence, since Irina Wakar, in the text entitled Kazimir Malevich “The Black Square”. The story of one masterpiece (Казимир Малевич “Черный квадрат”. История одного шедевра) states therein: “Of course, The Black Square is not an ordinary painting; perhaps it is not a painting at all, even if it bears all the external characteristics of a work of art" (Вакар 2015: 6). The question as to what The Black Square is did in fact occur to the painter himself, as well as art critics and historians. The authors of interesting and important academic papers see it as a sign of tefillin (Кацис 2005), a Masonic symbol (Турчин 2003), the infinite space of darkness, the beginning of a new subject-free art movement, and others besides (Карасик 2007). For my part, in referring to the Wakar

* Corresponding author: Diana Oboleńska, Instytut Rusycystyki i Studiów Wschodnich, Wydział Filologiczny Uniwersytetu Gdańskiego, ul. Wita Stwosza 51, 80-308 Gdańsk; e-mail: diana.obolenska@ug.edu.pl. 
quote, I would like to conduct a little experiment, right in line with the idea expressed in the wording of Imaginatio et Actio. A word of warning may be necessary, in that this experience does not pretend to find a definite answer, but merely strikes up a conversation instigated by Wakar's assertion that The Black Square is more than just a painting. This brief experience I allow myself to call an experiment for the sole reason that what is important in this case is not only the end result, but also the very course of events.

In order to set off on this experimental journey and define the area of research, I shall refer to the words of the master ${ }^{1}$, Malevich himself. Four years after The Black Square was presented to a wide audience in a text called Suprematism (square, circle, semaphore of the contemporary) (Супрематизм (Квадрат, круг, семафор современности)) Malevich wrote:

I invented nothing; I only felt the night inside of myself and saw something new, something called Suprematism, which clarified itself within me as a black plane, which formed a square, then a circle. In them I saw a new world of colours, but that was a long time ago, and now it comes alive before our very eyes. In the world it functions as an emblem and a sign - a night in which a morning of new auroras is born (Малевич 2004: 111).

In this brief quotation there are two interpretive signs that I would like to use for the experiment: the noun (emblem) and the repeating verb (I saw). The time difference that separated the first presentation of the work and the comment on it is not a problem at all; indeed, it is highly advisable - a point to which I shall return in due course.

So, is The Black Square really a kind of emblem, and if so, what? Well, this experiment is an attempt to compare three categories of meaning - the classic emblem, the esoteric/ alchemical emblem and The Black Square included in the scope of what determines an emblem - and to establish common semantic areas that codify the separate spaces in which the differences function.

The art of creating emblems, as a fully developed system, triumphed during the Renaissance. Although sources may be sought in earlier centuries ${ }^{2}$, it was in thriving Europe that an idea developed regarding a graphical symbol as the spokesperson for hidden meanings, sometimes secret, concerning the nature of man and the world (cf. Marsilio Ficino). All this was in the context of the discovery made in 1419 on the island of Andros. This discovery, taken to Florence, was a work written in Greek entitled Hieroglyphica by a writer named Horapallo. This text opened up a world of mysterious Egyptian hieroglyphics, recognising them as secret signs. It was a source of Renaissance fascination with a sign or symbol that expressed the figurative representation of what was inexpressible by words. More recent editions of works devoted to emblem creation appeared, beautifully decorated with graphical

1 The term "master" can be treated in a direct way, as an exceptionally gifted painter, or in the context of the esoteric, as indicated in his text Russian researcher W. Turczin (Турчин 2003).

2 The term "emblem" was already in use by ancient writers - Pliny, Cicero. In the Middle Ages there was a motto - a graphical representation of the coat of arms with an added inscription or slogan. The father of how to structure emblems is considered to be Andrea Alciati along with his work Emblematum liber. See (Pelc 2002; 1996; 1973). 
drawings (Andrea Alciati Emblematum liber). In the seventeenth century, this trend manifested itself as a series of hermetic works that used emblems to reveal the mysteries of the world to the initiated. Emblemata, written by Jean-Jacques Boissard and published by Theodore de Bry may be cited here, as well as the alchemical emblematic treatise Atlanta Fugiens by Michael Maier (see Клоссовски 2015). The second concurrent trend did not interpret any esoteric codes within an emblem, but instead used it for didactic purposes - for example, in the exempla style of moralistic literature.

In each of the two representations, the emblem was characterised by the same construction, usually tripartite - the illustration bore an inscription, which was the main title or motto, and a subscription, a so-called commentary (Figs 1 and 2) ${ }^{3}$.

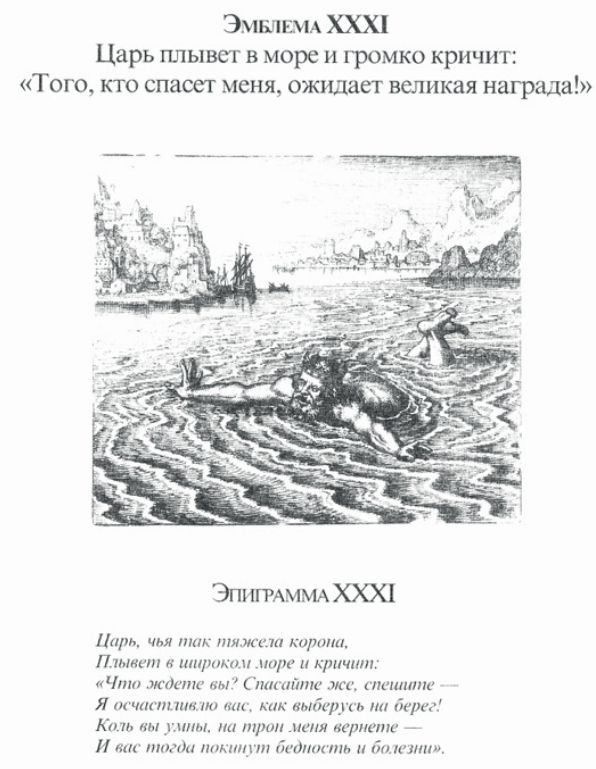

Fig. 1. Drawing made by Tadeusz Makowski

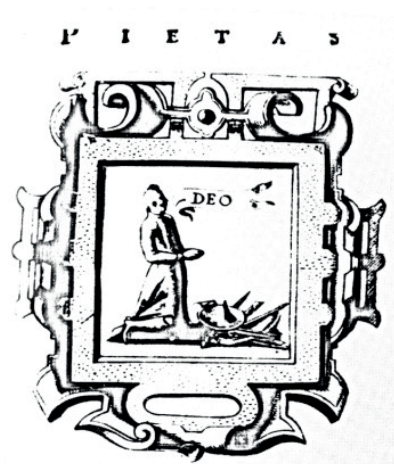

HErculis ad poftes olim VeIENTr's arma $H_{\text {Fixer at, emerita Jumbola militice. }}$ Fam forseneruis. Sed cui pia roborat artus $V i s$, contra armatos jolus inermis age. Quin Celumpenetrare libet, Piftate Fidegve. His victus regnum porrigit ipie Drvs. Sed for ran nimis bec paradoxa videntur: At ibuiu Fruma lagie LoNides tefera militza.

Fig. 2. Drawing made by Michael Maier

Apart from differences in the content provided by these two types of emblems, there was another important principle in the creation of an esoteric emblem (alchemical, in our example). What was not uncommon and highly appreciated in the work of an adept alchemist ${ }^{4}$, acting as an illustrator or cooperating with the artist, was an aspect that determined

3 The illustration on the left comes from the book by (Pelc 2002). This is a drawing made by Tadeusz Makowski, published in Vilnius in 1610. The illustration on the right comes from a book by (Майеp 2004). The original motto of the alchemical epigram reads: "Rex natans in mari, clamans alta voce: Qui me eripiet, ingens praemium habebit".

4 In this case, the term adept is understood as someone in the know, as proposed by Fulcanelli. 
the extent of a student's initiation - the esoteric imagination ${ }^{5}$. Some of the existing emblems, which are structurally related to the same treaties, are a direct transmission of a higher reality, while some are a cryptic game played with the recipient. In other words, this was secret content transmitted in the form of an image, bearing some text - a puzzle for the student to solve. This mystery was obtained by the adept through the imagination, which also accounted for the decryption. This was possible by changing the visual code that, through the imagination of the esoteric, was created not only by the creator, referred to as a cosmic force, but also by the recipient, or the alchemist. The chain of meaning depended on the spiritual capabilities of the recipient ${ }^{6}$, who reimagined the information possibly in accordance with the process of understanding through perception/formation. Such an alchemical emblem could be not only encrypted information at the stage of transmutation, but a kind of philosophical and esoteric meditation on the essence of events. One must admit that this was a remarkably convenient form of communication with possibilities of transmutation - practical knowledge of the actual transformation of the material world into the spiritual world. The experience of imagination in the case of an emblem's author did not only stand for the veracity of the information transmitted, but also served as an activator for the prepared recipient ${ }^{7}$.

So, on the one hand, the king swimming in the sea who features on Maier's emblem 31 may be a representation of the alchemical element sulphur (different from the modern notion of the chemical element), which is in a state of dilution or rot (putrefactio) and a process of cleansing or drying should be carried out, which leads the alchemist to the desired results - moving on to the next stage of transmutation. The fact that this is a very important procedure is indicated by the sulphur, as represented by the king (sеe Клоссовски 2015: 114). Another semantic point of reference is the sea in which the king swims. It is an extremely vast alchemical symbol, with a complex semantic structure. The sea can be marked out by an alchemical road - a wet process of transmutation (there is also a dry version involving fire). In the philosophical-alchemical sense, this could indicate a state of unconsciousness with everything or being purged from him - a concrete conscious element that forms a connection with the spiritual state. This form of shadow from the shadow aspect found in Jungian terminology - the unconscious aspect of the spirit - can, however, through an active imagination, be made aware, personified and, therefore, understood (Franz 2015). In the background of the emblem we see a ship - a symbol of the tools that call up the subconscious - but there is no bridge spanning the banks, which means that this is still an early stage and the misterium coniunctionis lies ahead of the alchemist. As an example, one may recall a text written by our alchemist and fellow countryman, namely Michael Sendivogius:

\footnotetext{
5 Due to the diversity of interpretation of the concept of imagination, it is made more specific in the form of the adjective esoteric, which envisages the participation of force majeure. See also (Starobiński 1972).

6 It was in the Renaissance, in the heyday of emblematic art, that the concept of esoteric imagination became a way of seeking other cognitive abilities: per. Ficino, Mirandolla et al. See (Swieżawski 1983).

7 This is exactly the case with initiatory literary texts, capable of specific symbolic impact on the spirituality of the recipient. I write about this in the book (Oboleńska 2014).
} 
It happened once that traveling through many years of my life [...] by some strange act of God I was cast upon the coast of a great sea. [...] But when I saw melusines and nymphs drifting to and from there on the coast, weary too from my previous toil and immersed in a variety of thoughts - the lapping of the water sent me to sleep, and after I had quietly fallen asleep, a strange vision came to me in a dream.

I saw Neptune grey and aged emerging from our sea [...]. After a friendly greeting, he led me to the most beautiful island (Sędziwój 1971: 203-204).

It is in this remarkably mysterious description that we see the same procedure of encryption, corresponding not only to the stage of transmutation but also indicating the vision of the author, which may most likely be referred to as the imagination ${ }^{8}$.

When we see the construction of what lies behind the esoteric emblem, the question arises as to whether Malevich's The Black Square can be included in this semantic scope, and ultimately if it is an emblem at all, as the author himself referred to his own work. It seems that it is.

If we take into account all the aspects associated with the creation and existence of this painting in the mind of the recipient, it represents the three basic structural components of an emblem. A less obvious matter in the emblematic structure is in this case the subscription, or comment, and the inscription, the so-called motto. At the 1915 exhibition, there was no text to accompany the painting (Fig. 3) .

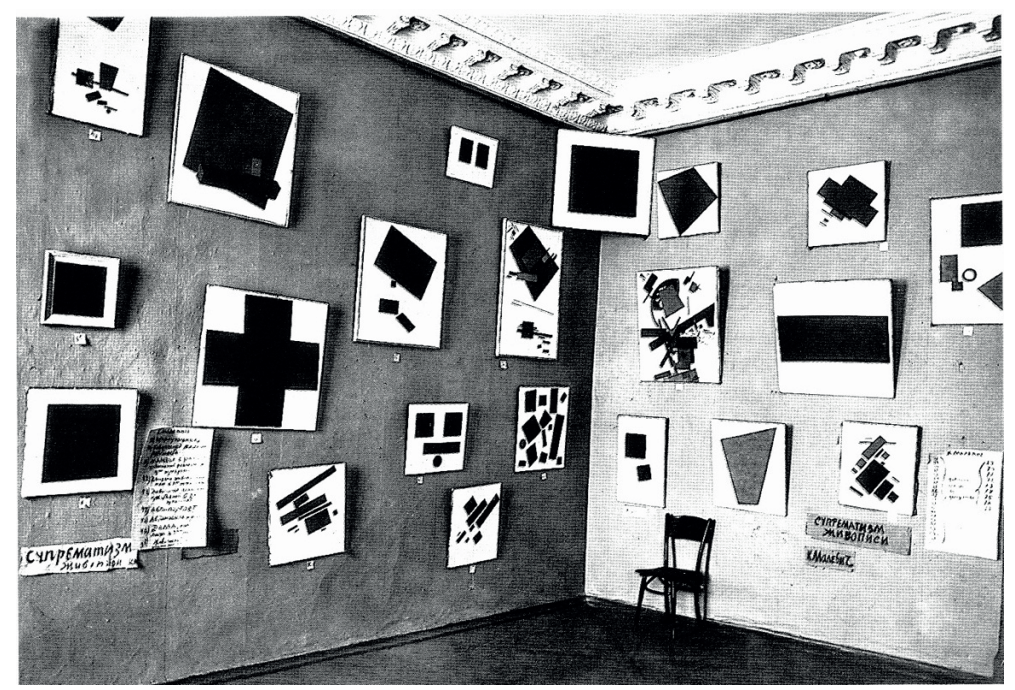

Fig. 3. The Black Square by Kazimir Malevich at the 1915 exhibition

8 This is exactly the case with initiatory literary texts, capable of specific symbolic impact on the spirituality of the recipient. I write about this in the book (Oboleńska 2014).

9 The photo comes from the catalogue (Вакар 2015). 
The painting's title was probably suggested by Malevich himself, since the work already bore this name when it arrived at the retyakov Gallery. What about the inscription? Looking at this photo, in which The Black Square is hanging in the top corner, it is impossible not to recall here the concept proposed by Georges Didi-Huberman - the virtual side of the painting (Didi-Huberman 2011). Didi-Huberman, in discussing the history of the creation and specific location of Fra Angelico's fresco Annunciation, also interprets the work with the help of an element that does not fall directly within the scope of representation. Didi-Huberman points out that when a small window is opened in the cell where the fresco is painted on the wall, sunlight completely fills the space of the cell and the fresco, which seems to emanate a new light, thereby eliciting the appropriate "form" of religious experience in the receiver.

The "Empty" (or rather virtual) side corresponds to the closed lips of the angel on the fresco - both of these elements indicate one mystery, one virtuality. This is the future birth of the Word who became flesh, and who in the Annunciation begins to form somewhere in the depths of Mary's body. Now we understand that the strong lighting of the image that is denudation, or catharsis, would make the mural more mysterious - like a body sanctified in crystal water - so that the mystery, which from the beginning avoided representation, could become virtual (Didi-Huberman 2011: 21).

Thus, the virtual side of the painting is a kind of apposition, commentary or motto of the artist, addressed to the consciousness or emotions of the recipient. In the case of The Black Square, whether this was supposed to recreate a sacred place - the corner of the room - by the inclusion of Orthodox icons ${ }^{10}$, or if it only served as a provocation and, or perhaps at the same time a means of distinguishing this picture, in any case it has its own interpretative virtual side - to guide the recipient towards the correct interpretation.

Finding the subscription is a much simpler task, in that Malevich wrote an indefinite number of texts devoted to Suprematism and to The Black Square as a kind of manifesto of that direction. Here are a few examples:

The square is not a form of the subconscious. It is a creation of intuitive reason.

The face of a new art!

The square is a living, royal young man.

This is the first step of pure creativity in art. Previously, they were naive copies of nature and deformity (Малевич 2004: 32).

Considering the canvas, primarily we see in it a window through which life shines. The suprematist canvas represents white space, not navy. The reason is clear - navy does not give a real representation of infinity (Малевич 2012: 55).

Malevich's theoretical texts are, in fact, a kind of never-ending attempt to reveal the essence, the act of creation, made by the suprematist. This is a reproduction of the painting in the form of content appearing throughout the whole oeuvre of Malevich. The time lapse between the creation of the painting and the text devoted to it, as I mentioned above, can be

10 Malevich in a letter to Alexandre Benois in connection with the "0.10" exhibition called The Black Square "an icon of its times", indicating that this interpretation is not without foundation. See (Вакар 2004). 
significant, which leads us to another, final element of the esoteric emblem - the condition for the existence of a vision or imagination in the spiritual consciousness of the artist. Malevich repeated over and over again that The Black Square, as a symbolic object, was a kind of revelation. Studies conducted on the canvas revealed that there had been another cubist painting composition that was then covered by the black square ${ }^{11}$. Some scholars think that the suddenness of the square's revelation did not allow Malevich to even prepare a separate canvas, while others argue that the meaning and significance of the square turns out to be superior to all the previous work of Malevich. How it was in reality is known only to the artist himself. He did not leave any precise information about the course of the event. However, the value, strength and emotional impact of the visual experience was repeatedly emphasised by the painter. The objectivity of the vision leads one to the assumption that perhaps it was really a question of imaginary experience.

The suprematist square turned out to be the element from which a new form of expressing feelings was established in Suprematism. So, this square on a white background is a form that is created by the feeling of the void of nonexistence (Малевич 2004: 109).

Through the entire convergence of constructive-semantic forms of The Black Square, with the esoteric emblem there appears an element of significant discrepancy, which also grows on the basis of Malevich's theoretical texts. As mentioned above, they are a multiplied attempt to define, clarify and build a conceptual structure of the vision that occurred. The painter refers in the texts to the cognitive-symbolic as well as the spiritual-psychological aspect, while trying to capture the formal essence of the square. "Knowledge of the world is not accessible to a painter; he can only feel it" (Малевич 2012: 77).

There is a growing impression that Malevich not only communicates what "was given to him", but he tries to plunge into the essence of the event, looking for words to identify and assimilate the overriding category, which in this case is symbolism of the geometric form (see: Белый 1994). Nevertheless, the esoteric emblem expresses the reality that the author had already assimilated and that aims to provoke the recipient to reflect.

It seems that this minor disturbance allows the painter to capture an additional aspect thanks to which the significance of the black square is doubled. This aspect is the category of movement. "An aesthetic act does not remain immobile but is in motion and takes part in the formation of new forms" (Малевич 2012: 83). The square is flexible matter that is in motion and takes new forms: a circle, a triangle, and a cube; in later stages of creation it transforms into whole spatial compositions, called architectons. In this case, movement means the reimagining of "the void of nonexistence" in the creative principle, determined by new forms, a new symbolic encryption of reality. Thus, The Black Square not only corresponds to an esoteric emblem, but is probably a modernised form, functioning thanks to the artist's ability to break through the static by including in the conceptual scope of this work not only an element such as the virtual side of a painting but, above all, the imagination of the recipient.

\footnotetext{
11 See (Шатских 2004: 7).
} 


\section{REFERENCES}

Didi-Huberman, Georges. 2011. Przed obrazem. Pytanie o cele historii sztuki, trans. B. Brzezicka, Gdańsk: Słowo/ obraz terytoria.

Franz von, Marie-Louise. 2015. Alchemia. Wprowadzenie do symboliki i psychologii, trans. M. Kalinowska, Poznań: Zysk i S-ka.

Oboleńska, Diana. 2014. De Imaginatione. О эзотерической имагинации в русской культуре начала XX века, Gdańsk: Wydawnictwo Uniwersytetu Gdańskiego.

Pelc, Janusz. 1996. Emblematy, książki emblematyczne. Problemy teorii a praktyka twórców, "Barok" 1(5): 33-50.

Pelc, Janusz. 1973. Obraz, stowo, znak: studium o emblematach w literaturze staropolskiej, Wrocław: Ossolineum.

Pelc, Janusz. 2002. Stowo i obraz na pograniczu literatury i sztuk plastycznych, Kraków: Universitas.

Sędziwój, Michał. 1971. Traktat o kamieniu filozoficznym, trans., intro. and commentary R. Bugaj, Warszawa: PWN.

Starobiński, Jan. 1972. Wskazówki do historii pojęcia wyobraźni, trans. W. Kwiatkowski, "Pamiętnik Literacki" 4: 217-232.

Swieżawski, Stefan. 1983. Dzieje filozofii europejskiej XV wieku. Człowiek, vol. 6, Warszawa: Akademia Teologii Katolickiej.

Белый, Андрей. 1994. Эмблематика смысла, in: Александ Казин (ред.), Критика. Эстетика. Теория символизма в 2-х томах, т. 1, Москва: Искусство.

Вакар, Ирина. 2015. Казимир Малевич. “Черный квадрат”. История одного шедевра, Москва: Третьяковская галерея.

Вакар, Ирина (ред.). 2004. Малевич о себе. Современники о Малевиче. Письма. Документыл. Воспоминания. Критика. В 2-х тm., Москва: RA.

Кацис, Леонид. 2005. Идеология витебского Уновиса, Иерусалимский Храм и Талмуд (Квадраты К.С. Малевича и Эль-Лисицкого), “Toronto Slavic Quartely” 12.

Карасик, Ирина. 2007. Приключения “Черного квадрата”, in: Приключения “Черного квадрата”: каталог выставки, Санкт-Петербург: Государственный Русский музей.

Клоссовски, Станислав. 2015. Золотая игра. Алхимические гравюры XVII века, пер. А. Кау-Тен-Чжи, Москва: Клуб Касталия.

Майер, Михаил. 2004. Убегающая Аталанта, пер. Г. Бутузов, Москва: Энигма.

Малевич, Казимир. 2012. Супрематизм. 34 рисунка, in: Казимир Малевич, Черный квадрат. Манифестыл. Декларации. Статьи, Санкт-Петербург: Азбука.

Малевич, Казимир. 2004. Супрематизм (Квадрат, круг, семафор современности), in: Александра Шатских (ред.), Собрание сочинений в пяти томах, т. 5, Москва: Гилея.

Турчин, Валерий. 2003. “Другое искусство” при свете теософии. Опыт рубежа веков и “русский вклад”, in: Георгий Коваленко (ред.), Символизм в авангарде, Москва: Наука.

Шатских, Александра. 2004. Малевич после живописи, in: Казимир Малевич, Собрание сочинений в пяти томах, т. 3, ред. А.С. Шатских, Москва: Гилея. 


\section{EMBLEMAT JAKO HIEROGLIF IMAGINACJI. CZARNY KWADRAT KAZIMIERZA MALEWICZA}

Artykuł zakłada swoisty eksperyment porównawczo-sensualny bazujący na pojęciu emblematu ezoterycznego i na formie wyrazu artystycznego, jakim jest Czarny kwadrat Kazimierza Malewicza. Nakładając jedno pojęcie na drugie, uzyskuje się rezultat pozytywny, który podsuwa kolejną propozycję odczytania tego suprematycznego obrazu jako doświadczenia imaginacyjnego.

Słowa kluczowe: Czarny kwadrat, Kazimierz Malewicz, emblemat ezoteryczny 